\title{
A study of the pharmacokinetics of clindamycin in normal subjects and patients with chronic renal failure
}

\author{
J. B. EASTWOOD \\ M.B., M.R.C.P. \\ P. E. GOWER \\ B.SC., M.D., M.R.C.P. \\ Department of Medicine, Charing Cross Hospital Medical School, Hammersmith, London
}

\begin{abstract}
Summary
A single dose of $150 \mathrm{mg}$ clindamycin was given to nine patients with terminal renal failure being treated by maintenance haemodialysis and the blood levels were measured. Four of these patients were studied during haemodialysis and five between haemodialyses. Clindamycin (150 mg) was also given orally to fous: normal subjects.
\end{abstract}

The mean serum half-life in the normal subjects was $2.15 \mathrm{hr}$. For the dialysis patients the mean serum halflife off dialysis was $1.58 \mathrm{hr}$ while that on dialysis was $1.85 \mathrm{hr}$.

There is evidence that clindamycin is excreted normally in chronic renal failure and that blood levels are not affected by haemodialysis. Normal adult doses, 150-300 mg four times a day, can be given safely in patients with chronic renal failure.

\section{Introduction}

Clindamycin (7-chloro-7-deoxylincomycin is an antibacterial agent active against many Grampositive organisms (McGehee et al., 1968).

Patients treated by maintenance haemodialysis are known to be subject to Gram-positive infections, especially those caused by staphylococci. Coagulasepositive staphylococci have been reported as causing infections of the Scribner shunt or Brescia-Cimino fistula (Clunie, Martin and Nolan, 1967; Curtis et al., 1969; Levi, Robson and Rosenfeld, 1970). These infections may result in septicaemia. Although drugs of the penicillin group remain the treatment of choice for staphylococcal infections, strains of staphylococci resistant both to penicillin and cloxacillin are being found increasingly. These organisms are often resistant also to drugs of the cephalosporin group. Any addition to the number of antistaphylococcal compounds available is welcome, particularly as a number of patients may be allergic to drugs of the penicillin group. It would be an advantage if such a compound was non-toxic and excreted by pathways other than the kidney so that normal adult dosage could be given.

The work of Cimino and Tierno (1969) has suggested that in patients with terminal renal failure, the serum half-life of clindamycin is greater than normal both during and between haemodialyses. This report prompted the present study to determine in more detail serum levels and serum half-life of clindamycin in patients with terminal renal failure, both during haemodialysis and between haemodialyses. At the same time data are given for four normal subjects.

\section{Methods}

Nine patients and four normal subjects were studied. The patients were dialysed twice weekly for a total of $28 \mathrm{hr}$ using a standard Kiil dialyser with cuprophane membranes (PT 150). Four patients were given $150 \mathrm{mg}$ of clindamycin orally just before dialysis started; five other patients were given $150 \mathrm{mg}$ of the drug the day after a dialysis. Blood was collected from the nine patients just before the drug was given and at $45 \mathrm{~min}, 75 \mathrm{~min}, 2 \mathrm{hr}, 4 \mathrm{hr}$ and $6 \mathrm{hr}$ intervals after administration of the drug. Four healthy male volunteers were given $150 \mathrm{mg}$ of clindamycin $1 \mathrm{hr}$ after breakfast and blood samples were taken at the same times as for the patients with renal failure.

All blood samples were collected in heparinized tubes, centrifuged immediately and stored at $-30^{\circ} \mathrm{C}$. Assays were carried out by the well-plate diffusion method, using Sarcina lutea ATCC 9341. Wherever possible a standard curve was prepared for each subject using his own pre-dose serum; otherwise the standard curve was prepared in $0.1 \mathrm{M}, \mathrm{pH} 7 \cdot 9$, phosphate buffer. The half-life of clindamycin was determined after analysis of the data by the method of least squares using a computer.

\section{Results}

Table 1 shows the ages and weights of the patients and normal subjects together with the plasma levels of clindamycin at the times stated. For all four patients on dialysis, peak levels ranging between 2.34 and $3.50 \mu \mathrm{g} / \mathrm{ml}$ were found at $45 \mathrm{~min}$. By $6 \mathrm{hr}$, levels approaching the lowest limit of sensitivity of the assay method were found.

Similar peak levels were found in patients between dialyses $(2 \cdot 16-3 \cdot 50 \mu \mathrm{g} / \mathrm{ml})$. In three of these patients 
TABle 1. Plasma levels of clindamycin in patients with advanced renal failure, on and off dialysis, and in normal subjects after a single $150 \mathrm{mg}$ oral dose of the drug

\begin{tabular}{|c|c|c|c|c|c|c|c|c|c|}
\hline \multirow[b]{2}{*}{ Patient } & \multirow{2}{*}{$\begin{array}{c}\text { Age } \\
\text { (years) }\end{array}$} & \multirow{2}{*}{$\begin{array}{l}\text { Weight } \\
\text { (kg) }\end{array}$} & \multicolumn{5}{|c|}{ Clindamycin level $\mu \mathrm{g} / \mathrm{ml}$} & \multirow{2}{*}{$\begin{array}{l}\text { Half-life } \\
\text { (hr) }\end{array}$} & \multirow{2}{*}{$\begin{array}{c}\text { Mean } \\
\text { half-life } \\
\text { (hr) }\end{array}$} \\
\hline & & & $45 \mathrm{~min}$ & $75 \mathrm{~min}$ & $2 \mathrm{hr}$ & $4 \mathrm{hr}$ & $6 \mathrm{hr}$ & & \\
\hline \multicolumn{10}{|c|}{ On dialysis } \\
\hline VO & 28 & 45 & $3 \cdot 50$ & $2 \cdot 60$ & $2 \cdot 00$ & $1 \cdot 17$ & 0.57 & $2 \cdot 1$ & \multirow{4}{*}{$1 \cdot 85$} \\
\hline $\mathbf{R} \mathbf{R}$ & 31 & 70 & $2 \cdot 60$ & $1 \cdot 80$ & $1 \cdot 33$ & 0.53 & $0 \cdot 29$ & $1 \cdot 7$ & \\
\hline ER & 54 & 59 & $3 \cdot 10$ & $2 \cdot 70$ & $2 \cdot 15$ & 0.99 & 0.39 & $1 \cdot 7$ & \\
\hline $\mathrm{BF}$ & 34 & 58 & $2 \cdot 34$ & $1 \cdot 75$ & $1 \cdot 38$ & 0.75 & $0 \cdot 31$ & 1.9 & \\
\hline \multicolumn{10}{|c|}{ Off dialysis } \\
\hline CS & 28 & 47 & 1.03 & $2 \cdot 85$ & 1.42 & $0 \cdot 32$ & $<0.25$ & 0.9 & \multirow{5}{*}{$1 \cdot 58$} \\
\hline BT & 27 & 51 & $2 \cdot 75$ & 2.02 & $1 \cdot 37$ & 0.61 & 0.25 & $1 \cdot 5$ & \\
\hline MB & 22 & 75 & 0.55 & 0.58 & $2 \cdot 16$ & $1 \cdot 10$ & 0.39 & 1.6 & \\
\hline MH & 34 & 56 & $3 \cdot 17$ & $2 \cdot 68$ & $2 \cdot 15$ & 1.02 & 0.41 & 1.8 & \\
\hline $\mathrm{KE}$ & 28 & 66 & $3 \cdot 50$ & $2 \cdot 91$ & $2 \cdot 52$ & 1.42 & 0.56 & $2 \cdot 1$ & \\
\hline \multicolumn{10}{|c|}{ Normal subjects } \\
\hline JE & 31 & 72 & $0 \cdot 26$ & 0.71 & 1.55 & 0.82 & 0.48 & $2 \cdot 4$ & \multirow{4}{*}{$2 \cdot 15$} \\
\hline VF & 29 & 68 & $1 \cdot 42$ & $1 \cdot 86$ & 1.47 & 0.82 & 0.44 & $2 \cdot 3$ & \\
\hline PT & 26 & 75 & $2 \cdot 28$ & $2 \cdot 32$ & $2 \cdot 10$ & $1 \cdot 12$ & 0.46 & $2 \cdot 0$ & \\
\hline PG & 35 & 75 & 1.85 & $1 \cdot 70$ & $1 \cdot 32$ & 0.65 & 0.30 & 1.9 & \\
\hline
\end{tabular}

the peak occurred at $45 \mathrm{~min}$, in one patient at $75 \mathrm{~min}$ and in one patient $2 \mathrm{hr}$ after ingesting the drug.

The peak values of the normal subjects were rather lower $(1.55-2.32 \mu \mathrm{g} / \mathrm{ml})$ and occurred rather later (at $45 \mathrm{~min}$ in one subject, $75 \mathrm{~min}$ in two subjects and at $2 \mathrm{hr}$ in the fourth subject) than in the patients with renal failure.

The mean half-life of clindamycin in the patients while being dialysed was $1.85 \mathrm{hr}$ (range $1.7-2 \cdot 1 \mathrm{hr}$ ) and between dialyses was $1.58 \mathrm{hr}$ (range 0.9-2.1 hr). The mean half-life for the normal subjects was $2 \cdot 15$ hr (range 1.9-2.4 hr).

\section{Discussion}

Wagner et al. (1968) reported that the half-life of clindamycin in normal subjects was $2.38 \mathrm{hr}$. This is close to our finding of $2 \cdot 15 \mathrm{hr}$. In normal subjects only $10-12 \%$ of orally administered clindamycin is recovered in the urine (Wagner et al., 1968; McGehee et al., 1968). The main pathway of excretion is extrarenal, probably being excreted mainly by the liver like lincomycin itself. It is to be expected, therefore, that the half-life of clindamycin is normal in patients with chronic renal failure. Our findings are in agreement with this suggestion. In contrast, Cimino and Tierno (1969) found that the half-life of clindamycin was prolonged in terminal renal failure to $3.36 \mathrm{hr}$. However, these authors studied blood levels after giving clindamycin every $6 \mathrm{hr}$ for $48 \mathrm{hr}$. Some accumulation of the drug may have taken place, and delayed absorption may also have occurred, both factors prolonging the half-life.

We are in agreement with Cimino and Tierno (1969) that dialysis has no effect on the half-life of clindamycin. This finding is surprising in view of the fact that clindamycin is approximately only $60 \%$ bound to serum proteins and has a mol. wt. of only 461.

The serum levels achieved after a dose of $150 \mathrm{mg}$ of clindamycin are well in excess of the reported MIC against many strains of Staphylococcus aureus (Meyers, Kaplan and Weinstein, 1969; Geddes et al., 1970; Phillips, 1971). This finding, together with the lack of toxicity of the drug, suggests that clindamycin should be a useful drug in the management of staphylococcal infections in patients on maintenance haemodialysis. Normal adult doses, $150-300 \mathrm{mg}$ four times a day, can be used.

\section{Acknowledgments}

We are grateful to Mr D. Hossack of Upjohn Ltd, Crawley, Sussex, for doing the clindamycin assays and to Upjohn Ltd, for supplying the clindamycin capsules.

\section{References}

Cimino, J.E. \& Tierno, P.M. (1969) Haemodialysis properties of clinimycin (7-chloro-7-deoxylincomycin). Applied Microbiology, 17, 446.

Clunie, G.J.A., Martin, A.M. \& Nolan, B. (1967) Intermittent haemodialysis. Insertion and care of the SilasticTefion cannula. British Medical Journal, 3, 88.

Curtis, J.R., Eastwood, J.B., Smith, E.K.M., Storey, J.M., Verroust, P.J., de WARdener, H.E., Wing, A.J. \& WolfSON, E.M. (1969) Maintenance haemodialysis. Quarterly Journal of Medicine, 38, 49.

Geddes, A.M., Bridgwater, F.A.J., Williams, D.N., Oon, J. \& GrimshaW, G.J. (1970) Clinical and bacteriological studies with clindamycin. British Medical Journal, 2, 703.

Levi, J., Robson, M. \& Rosenfeld, J.B. (1970) Septicaemia and pulmonary embolism complicating use of arteriovenous fistula in maintenance haemodialysis. Lancet, ii, 288.

MCGehee, R.F., Smith, C.B., Wilcox, C. \& Finland, M. (1968) Comparative studies of antibacterial activity in vitro and absorption and excretion of lincomycin and clinimycin. American Journal of the Medical Sciences, 256, 270. 
Meyers, B.R., Kaplan, K. \& Weinstein, L. (1969) Microbiological and pharmacological behaviour of 7-chlorolincomycin. Applied Microbiology, 17, 653.

Phillips, I. (1971) Clinical uses and control of rifampicin and clindamycin. Journal of Clinical Pathology, 24, 410.
Wagner, J.E., Novak, E., Patel, N., Chidester, C.G. \& LUMMIS, W.L. (1968) Absorption, excretion and half-life of clinimycin in normal adult males. American Journal of the Medical Sciences, 256, 25. 